\title{
Curiosity as Object: Egyptian Mumia in Early Modern Europe
}

\author{
Spencer Kales, * Department of Archaeology, Clark Honors College
}

\begin{abstract}
Throughout human history, people have maintained beliefs and practices that were meant to sustain health even though they seem, to the modern inquirer, to be quite ridiculous. A common source of medicinal material throughout history (even as recent as the $20^{\text {th }}$ century in some cases) was human remains, either long dead or freshly deceased. One of these human-based 'panaceas' was mumia, the pulverized or tinctured extract of human corpses-mummies-mostly from Egypt. A variety of products fell under this designation, and could be found in wide temporal and geographical range. The paper will address the procurement, manufacture, sale, and distribution of this macabre cure in order to argue that its ubiquitous nature led to its eventual fall from popularity.
\end{abstract}

Curiosity can be examined from any number of equally interesting perspectives. An inquisitor may choose to study the development of curiosity through ideas, concepts, or beliefs. One case, for example, is the natural philosophers of the early modern period that strove to understand how the world worked in the physical sense. Alternatively, one may pursue the history of curious objects, in which tangible materials, products, and artifacts are traced through time, and are used as a means of measuring change related to such objects. A class of such description is corpse medicine, the use of the deceased human body for its purported health benefits. A notable-and occasionally notorious-corpse medicine compound, commonly known as 'mumia'-has a complex history, spanning from the embalming chambers of the Pharaohs to the counters of $20^{\text {th }}$ century European pharmacies. Drawing from primary documents such as John Parkinson's Theatrum Botanicum, and John Sanderson's Travels in the Levant, as well as numerous modern scholarly opinions, this 'object' will be used to investigate evolving concepts of medical physiology, changes in geographical distribution via trade, and the effects of commercialization on its popularity and authenticity in $16^{\text {th }}$ and $17^{\text {th }}$ century Western Europe.

To better define objects as curiosities, Neil Kenny's text, The Uses of Curiosity in Early Modern France and Germany, explores how “to call an object 'curious' was to say both something about the way in which a human subject had crafted it and something about the way in which it was an object of human attention." ${ }^{1}$ Human attention can be measured in the sense

\footnotetext{
${ }^{1}$ Neil Kenny, The Uses of Curiosity in Early Modern France and Germany, Oxford: Oxford University Press 2004, 169.
}

\footnotetext{
*Spencer Kales is a senior in the Clark Honors College, studying Archaeology and Spanish. He has rowed for the university's team throughout his college career, and will be men's team captain this coming year. Spencer plans to pursue a law degree after graduation to work toward safeguarding cultural material and intangible heritage resources, and work against the worldwide illegal antiquities trade. Please send all correspondence to nvskiguy@aol.com.
} 
of how desired an object is, such as economical demand. Thus, Kenny claims that curious objects were "often commodified [...] endowing them with financial value" and "were often used in attempts to make money or else to boost their owner's prestige." 2 In order for such objects to have a market or monetary value, they needed to be "'rare', 'uncommon', 'exotic'. . 'beautiful' . . . 'noteworthy"' amongst similar descriptions. ${ }^{3}$ Logically, there would need to be a market for the exchange of curious objects, as the concept of value is incomplete without a group of people willing to pay said value. Kenny labels this market "the curious," and describes it as "nearly as socially diverse as it was geographically far-flung, embracing aristocrats and merchants, physicians and apothecaries, lawyers and clergymen of all denominations; but it was united in its preoccupation with the marvels of art and nature." 4 As such, it was not an exclusive group in terms of social status, but rather one of economic status. The value of an object was also related to how far it had been removed from its primary context, as "curious fragments tended to be the ones that were dislocated from their proper place, whether literally, in cabinets of curiosities, or figuratively - when they were bits of knowledge divorced from the context of a discipline to which they belonged."5 As the distance from the object's geographical source increased, so did its scarcity, and theoretically, its monetary and cultural value.

Following Kenny's definition, mumia is an object of curiosity. It was "human crafted" (as well as crafted from humans), and it was "commoditized" and sold to the public. Brought to Europe, it was "dislocated from [its] proper place" and 'divorced' from its original cultural context of Dynastic Egypt. One needs background knowledge about mummification to form a basis for mumia's original cultural context of Dynastic Egypt. Karl Dannenfeldt, in the The Sixteenth Century Journal, compiled a plethora of primary sources on the subject in his article "Egyptiona Mumia: The Sixteenth Century Experience and Debate." In 1516, Tome Pires, "a Portuguese apothecary and ambassador to China," described the process as "when the man dies they remove his intestines, lungs, etc., and throw in myrrh and aloes; then they sew up the corpse and put it in a sepulchre with holes." 6 This is an intensely simplified, yet adequate explanation. This 'apothecary' was likely working from information handed down, transmuted by ages of replication and translation. These factors contribute to the increasing murkiness that accompanies knowledge's endurance of time: a historical game of “telephone."

Knowing how a mummy was prepared for burial was important in distinguishing whether or not it would be of medicinal use, as not all mummies were prepared in the same fashion. The method described by Pires required more time, labor, and material, and was therefore reserved for nobility. In the twelfth century, the Islamic physician Abd Allatif wrote that "The mummy found in the hollows of the corpses in Egypt, differs but immaterially from the nature of mineral

\footnotetext{
${ }^{2}$ Ibid, 168.

3 Ibid, 169.

${ }^{4}$ Kenny, The Uses of Curiosity, 171.

5 Ibid, 176.

${ }^{6}$ Karl Dannenfeldt,"Egyptian Mumia: The Sixteenth Century Experience and Debate," The Sixteenth Century
} 
mummy; and where any difficulty arises in procuring the latter, may be substituted in its stead." 7 As Allatif was seen as an authority in contemporary Islamic physiology, his advice was passed down to future generations of physicians, thereby propagating the 'fact' that the two subcategories of mumia could be used interchangeably.

In reality, the 'mineral mummy' was an inorganic bitumenous petroleum (essentially very crude oil). The substance was collected from desert wells, or springs, and was not biologically derived from decomposed human flesh coupled with various compounds (such as aloe and myrhh). Robert Jacobus Forbes, in Studies in Early Petroleum History, suggests that “'Mumia' was a true 'pissasphaltos', that is a mixture of pitch and natural asphalt, whereas the original 'mummy' (or mumia primaria) was a waxy natural asphalt found in Persia."'8 Another type of mumia was "Pulvis Mumiae", which was made by pulverizing-hence Pulvis-desiccated burial wrappings, bones, flesh, as well as the herb compound that soaked these materials, into a powder that could be mixed into other medicinal remedies. ${ }^{9}$ Basing their opinions on those of well-known physicians such as Allatif, later physicians and apothecaries continued to expand their manufacture and prescription of mumia, leading to a burgeoning market for both the raw materials and the subsequent 'medicinal' compounds.

With the growth of the trade came the promise of a profitable mercantile endeavor. The mummy business was good, attracting merchants and unskilled laborers alike. By necessity, there were multiple levels or capacities of people involved. Who was sourcing the materials, doing the work to prepare the product; who was actually making the transactions or collecting the profits? Dannenfeldt reviewed an instance where a group of Egyptian locals employed in the trade were apprehended, and were "Brought before the provost, they confessed under torture that they were removing bodies from the tombs, boiling them in hot water, and collecting the oil which rose to the surface. The men were imprisoned." 10 These men would have been at the lower end of the hierarchy, doing the dirty, physical work of extricating the corpses and refining out the desired substance. This line of work can be seen as analogous to that of the rag and bone men of early modern Europe, who scrounged through graves and trash in order to supply the raw materials for the hungry paper manufacturing trade. ${ }^{11}$ Both trades needed unskilled labor in order to procure the necessary raw materials.

Working up from the bottom of the trade's hierarchy, a demographic pattern emerges that highlights the activity of Egyptian Jewish physicians, apothecaries, and merchants. Dannenfeldt outlines how "the use of Egyptian mummies in medicine was begun by an expert Jewish physician of Alexandria named Elmagar ... Other physicians of all nations followed his example and the widespread use of the drug caused Jewish merchants of Egypt to enter the lucrative trade by preparing dead bodies of all sorts and selling them to the Christians." ${ }^{12}$ From such

7 Dannenfeldt, Egyptian Mumia, 167.

${ }^{8}$ Forbes, RJ, More Studies in Early Petroleum History, Leiden: Brill 1959, 25.

9 Ibid, 25.

${ }^{10}$ Dannenfeldt, Egyptian Mumia, 16.

${ }^{11}$ Keller, Vera, In-class material, January 2014.

${ }^{12}$ Dannenfeldt, Egyptian Mumia, 170. 
historical examples, it seems that religious differences could be minimized when it came to the subject of marketplace exchange. Similarities could be drawn to Early Modern European anatomists scrambling for freshly dead people to dissect for their anatomical inquiries, as Professor Guerrini discussed in her lecture "The Ghastly Kitchen," as well as in her book Experimenting with Humans and Animals. ${ }^{13}$

The sale of counterfeit mumia to the undiscerning masses was a commonplace practice in early modern Egypt and Western Europe. The common person consuming mumia for its believed medicinal qualities would not likely have been able to tell the difference between Mumia Vera ("true" mumia from human corpses) and Mumia Primera-the bituminous mineral petroleum that had a longer documented history of medicinal use throughout the Levant. The fact that the two substances were fairly similar in appearance and texture (black and pitch-like) was combined with the 'sagacious' advice of the authoritative historical figures, such as Allatif, to make for a solid case as to the efficacy of this corpse medicine.

Word of such a miraculous panacea spread to European countries like France and England. The increasing popularity of mumia in Europe was in large part a result of historical travel writing, accounts of time spent in Northern Africa and the Levant, some of which were printed and sold to 'the curious'. But how did such travel accounts increase the demand for mumia amongst European physicians and apothecaries? Kenny proposes, "It was collecting more than narrating that curiosity fostered in travel-writing. Most travel accounts were not only narratives but also lists, catalogues, or inventories: 'curiosity' denoted inventory more than narrative." 14 As a result of such stints of travel, some Europeans would bring back 'curiosities', whether that be the object itself or a primary description, to pique the interest of their curious associates or readers.

However, Kenny argues that a shift occurred in the mindset of the curious, which may have entailed an "agonized early modern attempt to make curiosity useful."15 Some travel accounts, by acting more like "inventories", may have promoted the physical acquisition of curious objects, such as mummified remains. By increasing the demand for and actual importation of objects, ravel accounts augmented the apothecary use, resulting in the commodification of mumia on an international scale. Travel accounts that recorded curiosities are plentiful, but finding one to fit the exact context of this discussion took some deeper research. John Sanderson was an English traveler who was an agent of “'The Turkey Company,' which traded at this period in a 'joint stock', employing a number of factors in the East to sell the goods received from London and to invest the proceeds."16

${ }_{13}$ Anita Guerrini, Experimenting with humans and animals: From Galen to Animal Rights,Baltimore: Johns Hopkins University Press, 2003, 6-22.

14 Kenny, The Uses of Curiosity, 246.

15 Ibid, 246.

${ }^{16}$ John Sanderson, Travels in the Levant, xiii. 
The manuscripts were lost upon his death, but were eventually collected by William Petty, "an enthusiastic collector of old documents."17 The account, "His First Visit to the Levant," detailed Sanderson's business dealings in Egypt, Israel, and Syria. He described his arrival in detail: "Frome Alexandria I went the $19^{\text {th }}$ and came to Grand Cairo the $29^{\text {th }}$, passinge by land 1 $1 / 2$ day and a night to Rossetto, and ther imbarked up the river Nilus, our boat beinge drawne alonge the shore by the watermen Moors." 18 During his travels, he had time to explore for his own curiosity in addition to his business affairs. He documented some of the major historical and archaeological sites along his path:

\footnotetext{
The $28^{\text {th }}$ of April 1586 I went to see the Peramidis and Momia, beinge of three jentellmen of Jarmani intreated to accompany them. The next day we retorned. Thes Peramidis (one of the Seven Wounders ar divers, but espetially two, of a like bignes; at the bothome each 1000 paces about. One of them open, that in we went with wax candles lighted and up to the topp, wheare standith in a square rome a tombe hewed out of black marble or jett...[Also, the nearby Great Sphinx] “...ther is likewise a hudge figure of a head of stone, standinge upright to the necke out of the ground. ${ }^{19}$
}

As he was in the vicinity of such prominent ancient Egyptian architectural monuments, he was also exposed to a historical source of 'momia', a large cavernous mass grave, where locals were likely to collect their materials for the trade:

\footnotetext{
The Momia, which is some five or six miles beyound [the pyramids 'peramidis'], ar thowsands of imbalmed bodies, which weare buried thousands of years past in a sandie cave, at which ther seemeth to have bine some citie in the times past. We were lett doune by ropes as into a well, with wax candles burninge in our hands, and so waulked uppon the bodies of all sorts and sised [sized], great and smaule, and some imbalmed in little earthen potts, which never had forme; thes at the feet of the great bodies. ${ }^{20}$
}

Sanderson is likely describing a collective grave, where people of lower social, cultural, and economic means would have been buried. These types of graves would have been less-well sealed, as well as more plentifully distributed throughout the landscape, and therefore would provide a larger amount of the raw material needed for the trade, at least that of 'mumia vera.'

Sanderson describes the corpses' appearance and compositional attributes, where: “They gave no noysome smell at all, but ar like pitch, being broken; for [he] broke of[f] all parts of the bodies to see howe the flesh was turned to drugge, and brought home divers heads, hands, arms and feete for a shewe." ${ }^{21}$ The corpses were old enough to have lost their putrid scent, which also meant that they had stayed dry enough in this "sandie cave" to not decompose. The main end of mummification was removing the corpse's moisture, a catalyst in decomposition. Removing

\footnotetext{
${ }^{17}$ Ibid, $\mathrm{x}$.

18 Ibid, 40.

19 Ibid, 44.

${ }^{20}$ Sanderson, Journey to the Levant, 44.

${ }^{21}$ Ibid, 45.
} 
light, oxygen, and moisture greatly increases the preservation of organic material. The high temperature and low humidity of the Egyptian desert is also helpful. ${ }^{22}$

Sanderson attempted to understand how the "flesh was turned to drugge", and may have been investigating whether or not these particular bodies had been treated with pissasphaltum during their embalming, which would yield a black, sticky texture, as Dannenfeldt claims, “...authoritative writers had said asphalt was used in embalming [of] the bituminous mumia..." 23 Sanderson's log outlines his hope of having "a shewe" [show], in which he might display his collection of dismembered mummy appendages in a festive manner likely to engage the curiosity of friends and other guests upon his return to London. Providing tangible objects for the viewing pleasure of the folks back home was a key aspect of curiosity in practice. To further investigate the practice of the international movement or trade of mumia, Sanderson provided his readers with a first-hand account of such a transaction, where "We bought allso $600 \mathrm{lb}$. for the Turkie Company in pieces, and brought into Ingland in the Hercules, together with a whole bodie. They ar lapped [wrapped] in 100 doble of cloth, which rotton and pillinge of[f], you may see the skinne, flesh, fingers, and nayles firme, onelie altered blacke." ${ }^{24}$ This passage showed Sanderson's opinion of the cargo's physical appearance, which notably describes the mummy's "skinne [...] onelie altered blacke". The Turkey Company here was acting as an importer of mummy to England, of course, by cargo ship. But how were they able to bypass the 'laws', whether or not they were codified, meant to restrict the sale of Egyptian corpses? A previous editor of Sanderson's manuscript, by the name of Purchas, explained the transaction more indepth in a note:

It is contrabanda to sell of them but by friendship which William Shales [Sanderson's European trade contact in the Levant] had amongst the Moores (he having their language as perfect as English) with words and money the Moors will be entreated to anything. This body of momia after our arrivall was carried to the house of Sir Edward Osborne in Filpot Lane, in London, and there it was with the 600 pounds, til they were sold to the apothecaries. ${ }^{25}$

From Purchas' record, the answer is shown to be bribery, as in his opinion, "with words and money the Moors will be entreated to anything." This did not seem to have been attempted defamation of the Moors character on Purchas' account, but should rather be viewed as an illustrative example of the popularity and demand for mumia. People were willing to lie, cheat, and steal if necessary in order to profit from this trade, even risking imprisonment. Sanderson's account contrasts with Dannenfeldt's example of the poor locals who were jailed for being involved in the 'illicit' trade.

Why was this activity illegal? Were there specific laws against grave-robbing or exportation to Europeans? A likely explanation is that they were not wealthy enough to bribe their way past any 'laws' that were in place, that attempted to regulate the actions of these laborers, merchants,

22 Personal knowledge as an Archaeology major

23 Dannenfeldt, Egyptian Mumia, 166.

24 Sanderson, Travels in the Levant, 45.

25 Ibid, 45, footnote 1. 
and apothecaries. This note also further clarified the details of transporting the material, and was even specific as to the address of the distributor, "Filpot Lane" in London. The final portion of the mumia's journey to Europe would have been purchase by individual apothecaries, where it was to be prepared in a number of ways and sold to the corpse-medicine-consuming members of the public in hopes of curing whatever ailment they believed it should.

The supposed curative properties of mumia have been historically documented, mostly through well-known physicians, such as Abd Allatif. Another Arabic physician, Avicenna, was approximately contemporaneous with Allatif. His beliefs regarding mumia's curative properties were cited in A History of Egyptian Mummies: And an Account of the Worship and Embalming by Thomas Joseph Pettigrew:

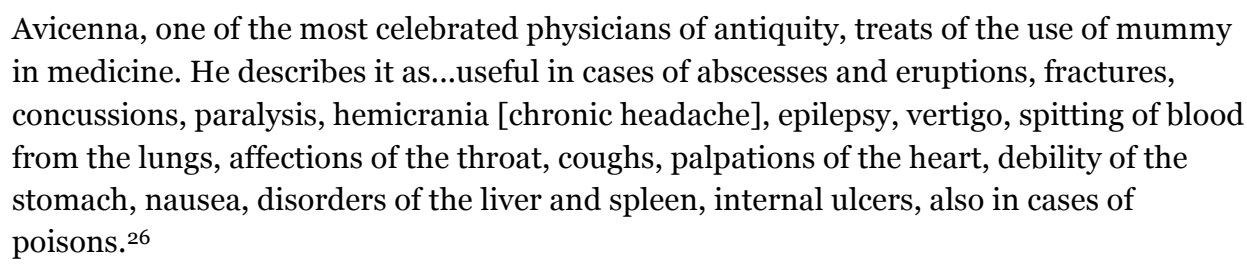

Avicenna believed that mumia would be helpful to administer to individuals suffering from these conditions, although one may anachronistically wonder how he thought paralysis would be mitigated by its use. Nevertheless, such notable authors heavily influenced later members of the field. For example, John Parkinson, a $17^{\text {th }}$ Century herbalist and botanist, continued the validation of mumia in medicinal applications. His Theatrum Botanicum; An Herball of Large Extent (1640) outlined a medicinal concoction containing mumia. An 'herball' was a kind of doit-yourself guide for using substances such as plants or minerals for their supposedly curative properties. The recipe for which follows:

\begin{abstract}
Let a sufficient quantitie of Rubarbe be steeped in cinamon water, which being strongly pressed forth, let it be stilled in a glasse Limbeck in balneo (sp?), until the water be drawne forth, and the substance remaining be of the thickness of honey, which keepe in a close covered pot or glasse, for the use aforesaid. The powder of Rubarbe, taken with a little Mumia and Madder rootes, in some red wine, dissolveth congealed or clotted blood in the body, happening by any fall, or bruise, and healeth burstings, and broken parts, as well inward as outward; the oyle likewise wherein it hath beene boyled, being anointed worketh the same effect: it helpeth the yexing, or hickocke [hichup?], and all fluxes of the belly, if it be toasted or dryed a little by the fire. ${ }^{27}$
\end{abstract}

Parkinson's Herball makes use of "the Theater of Plants," which grow naturally, but can also be domesticated in order to be harvested on a larger scale. The 'rubarbe' could have been locally sourced, but the 'cinamon' would most likely have been imported through international trade with more tropical locales. The mumia sticks out here as the sole ingredient not found in the "Theatrum Botanicum" of the world, as it was human-based. One may argue that it comprises naturally available elements into an 'unnatural'-that is, not occurring in nature-combination. The proposed effects seem to be blood-thinning in nature, as the poultice or syrup was thought

26 Thomas Pettigrew, A History of Egyptian Mummies, 9.

27 John Parkinson, Theatrum Botanicum, Ch. 2, 159. 
to "dissolve congealed or clotted blood" in the form of haematomas or contusions. These symptoms were also present in Avicenna's treatment, namely "spitting blood from the lungs." One contrasting characteristic is that Parkinson's use for mumia is more specific as to the conditions it was intended to treat. A possible explanation for this observation is that Parkinson documented a more specific recipe, a variety of ingredients including mumia, as opposed to Vicenna's more generalized list of symptoms supposedly treatable with mumia in general. Parkinson's Herball was well-known, and would have been referenced by apothecaries, as well as individuals, trying to heal themselves with what nature provided. ${ }^{28}$

Although it was popularly accredited as a miraculously curative substance, mumia was also the subject of attempted debunking throughout the height of its popularity. The obvious question exists: was it actually good for anything? Or did it have more of a placebo effect? How was it thought to function in the body? In addition to the petroleum substance bitumen, Richard Sugg, in Murder After Death: Literature and Anatomy in Early Modern England, proposes that the patients "were consuming the most vital spiritual essence of the human organism...they were eating the soul. The life force thought responsible for mummy's efficacy was identified most commonly with the "spirits" of the blood...both divine and routinely physiological." 29 There was even a supposed distinction concerning the age of the person, as this 'life force' was believed to be stronger if "the subject should be young, healthy, and prematurely killed, because "all living beings have a foreordained life span" and the remainder of that span can therefore effectively be drawn from their corpse." 30 This metaphysical explanation was apparently good enough for the patients receiving such treatment, given the commercial success and popularity of mumia, as demonstrated in Sanderson's account.

Neil Kenny explores the negative aspects of innovation driven by curiosity, where: "the danger was that curiosity might leave usefulness behind and go off on its own useless, speculative, error-strewn path instead of healing people. The deceitfulness of a prurient age lies in distinguishing the curious from the useful and in concentrating and expending its energies...on things which bring no practical benefit." ${ }^{11}$ In relation to mumia's effectiveness, Sugg discusses the $16^{\text {th }}$ century French surgeon, Ambroise Paré, who staunchly objected to the commonplace prescription of mumia, as "we are...compelled both foolishly and cruelly to devour the mangled and putrid particles of the carcasses of the basest people of Egypt, or such as are hanged, as though there were no other way to recover the bruised [patients]." ${ }^{2}$ In addition, he claims to have "tried mummy 'an hundred times' without success" in the treatment of his own patients. 33

In the above statements, Paré addressed some of the key points in the discussion. He noted how the majority of mumia was sourced from mass burials of lower-status people, such as those

${ }^{28}$ Class exhibit label, Recipe: The Kitchen as Laboratory in the West, 140o-20oo, 2.

${ }^{29}$ Richard Sugg, Murder After Death: Literature and Anatomy in Early Modern England,42.

${ }^{30}$ Sugg, Murder After Death, 42.

${ }^{31}$ Ibid, 42.

$3^{2}$ Ibid, 41.

33 Ibid, 41. 
described in Sanderson's travel log. He also doubted the authenticity of mumia, claiming that the majority was made from the remains of recently executed criminals, not 'real' mummies. Paré's critique on mumia's authenticity had historical basis, as the Egyptian Jewish physicians and merchants were frequently offering counterfeit mummy to their customers. According to Barbara Scholz-Böttcher's article "An 18th century medication "Mumia Vera Aegyptica"- Fake or authentic?" "Egyptian and European Jews were heavily involved in the trade of mummies."34 For reference, "Mumia Vera Aegyptica" means "true egyptian mumia", or at least that's what the apothecary would label it in effort to increase its validity. While Jewish apothecaries, physicians, etc., constituted a significant demographic involved in this trade, there were of course participants from a wide array of religious, ethnic, and national identities. "The increasing demand for, and commercial value of, real mummies, together with the restricted supply, resulted in an incentive for fraud and falsification." 35

There could only be so many known sources of authentic, ancient, mummified Egyptian corpses, so they had to get creative in order to stay competitive in the trade. Instead, they resorted to "dried cadavers of slaves that were filled with bitumen, or dried corpses of pilgrims to Mecca who perished in the desert sand, or those of travellers who had died in the Lybian Desert." 36 The average consumer would likely not be qualified to discern between the different types of mummy, or be able to distinguish "mumia vera" from "mumia prepared five years ago." Their ignorance would in turn increase the profit of the proprietors.

The international trade was not simply the transportation and sale of dried corpses. It was the exchange of ideas about physiology, apothecarial knowledge, and cultural beliefs: or, in other words, curiosities. The cultural interchange and cross-referencing that was responsible for the success and growth of the mummy trade also proved to be its downfall. As its use throughout Western Europe gained renown, it invited speculation from physicians like Ambrosie Paré, resulting its eventual disaccreditation. As the demand grew, the supply of ancient Egyptian mummies dried up, leading to the counterfeit substitution of any available corpse by merchants looking to strike it rich. The authenticity of mumia as a corpse medicine suffered as the 'remedy' reached the apex of its historical trajectory. Perhaps the Egyptians should have just kept their secrets ... under-wraps.

\section{ACKNOWLEDGEMENTS}

I'd like to thank Professor Vera Keller for her guidance in creating a focused thesis as well as her approval on this paper. It was for her class, HC431 The History of Experiment. I'd like to thank my friends Delaney Butler and Caellagh Morrissey (also of the Clark Honors College) for reading and providing suggestions for clarity and organization.

34 Barbara Scholz-Böttcher, "Mumia Vera Aegyptica," 2.

35 Scholz-Böttcher, "Mumia Vera Aegyptica," 2.

${ }^{36}$ Ibid, 2. 


\section{REFERENCES}

Dannenfeldt, Karl H., "Egyptian Mumia: The Sixteenth Century Experience and Debate," The Sixteenth Century Journal 16 (1985): 163-180, accessed March 10-15, 2014. http:/www.jstor.org/stable/2540910

Forbes, Robert Jacobus, More Studies in Early Petroleum History (Leiden: Brill, 1959.) http://books.google.com/books?id=_MgUAAAAIAAJ\&pg=PA1\&dq=Forbes, + RJ + Studies $+\mathrm{i}$ $\underline{\mathrm{n}+\text { Early }+ \text { Petroleum }+ \text { History\&hl=en\&sa }=X \& e i=6 w Q d U b K O s j x o A T h s I H 4 B g \& v e d=0 C C k Q 6}$ AEwAA\# $\mathrm{v}=$ onepage $\& \mathrm{q}=$ mumia\& $\mathrm{f}=$ false

Guerrini, Anita, Experimenting with humans and animals: From Galen to Animal Rights, (Baltimore: Johns Hopkins University Press, 2003), 6-22.

Keller, Vera, Class lecture material, Jan. 2014.

Kenny, Neil, The Uses of Curiosity in Early Modern France and Germany (Oxford: Oxford University Press, 2004). Print.

Parkinson, John, Theatrum Botanicum Or, An Herball of Large Extent, (Tho. Cotes, Complutense University of Madrid, 1640, digitized 2011), 159.

http://books.google.com/booksid=pFcfNkN8QGYC\&q=mumia\#v=snippet\&q=mumia\&f=fal $\underline{\text { se }}$

Pettigrew, Thomas Joseph, A History of Egyptian Mummies: And an Account of the Worship and Embalming, (Cambridge: Cambridge University Press, 2013 reprint), 9. http://books.google.com/booksid=bZ9sAAAAQBAJ\&pg=PA9\&lpg=PA9\&dq=avicenna + mu mia\&source $=$ bl\&ots $=$ FTFYyqoE7u\&sig $=2 \mathrm{gkA0} 5 \_74 \mathrm{uR} \_\mathrm{d} 3 \mathrm{VIcPl} 2 \mathrm{ebXF} 7 \mathrm{k} \& \mathrm{hl}=$ en\&sa $=\mathrm{X} \& \mathrm{ei}=$ CxIhUDLMtfaoASXsoDQCw\&ved=oCEgQ6AEwCA\#v=onepage\&q=avicenna\%20mumia\&f= false.

Sanderson, John, The Travels of John Sanderson in the Levant, 1584-16o2,(London: Hakluyt Society, 1931), 36-54, print.

Scholz-Böttcher, Barbara, "An 18th century medication "Mumia vera aegyptica" -Fake or authentic?” Organic Geochemistry 65 (2013), 2:

http://dx.doi.org/10.1016/j.orggeochem.2013.09.011

Sugg, Richard, Murder after Death: Literature and Anatomy in Early Modern England, Ithaca: Cornell University Press, 2007, print.

Unknown Student, Class exhibit label, Theatrum Botanicum, Recipe: The Kitchen as Laboratory in the West, 1400-200o, label 2. Journal, 16 (1). 